\title{
TEORI PENDIDIKAN MORAL MENURUT EMILE DURKHEIM RELEVANSINYA BAGI PENDIDIKAN MORAL ANAK DI INDONESIA
}

\section{Setia Paulina Sinulingga}

Sekolah Bina Kasih, Jambi

Email: paulinaulin17@gmail.com

\section{Abstrak}

Moral adalah bekal dalam mengembangkan diri. Masalah moral, adalah masalah yang menjadi perhatian manusia di mana saja, baik dalam masyarakat yang telah maju, maupun dalam masyarakat yang masih terbelakang. Hal itu dikarenakan, kerusakan moral seseorang mengganggu ketenteraman yang lain. Jika dalam masyarakat banyak orang yang rusak moralnya, maka guncanglah keadaan masyarakat itu. Pendidikan moral bagi anak dapat mengubah perilaku anak, sehingga jika sudah dewasa lebih bertanggung jawab dan menghargai sesamanya dan mampu menghadapi tantangan jaman yang cepat berubah. Peningkatan pertimbangan moral pada diri anak yang dirancang melalui pendidikan di sekolah, dapat membantu pembentukan kepribadian anak, karena dengan terbentuknya pertimbangan moralnya, anak akan berperilaku sesuai dengan cara berpikir moral yang ada padanya. Tiga unsur yang ditetapkan oleh Durkheim, untuk bisa menjadi pribadi yang bermoral yang pertama adalah disiplin; kedua adalah keterikatan pada kelompok; ketiga adalah otonomi. Ketiga unsur ini dibutuhkan setiap individu untuk bisa menjadi pribadi yang bermoral. Dan tindakan moral pada hakikatnya merupakan fokus sentral dari dunia moral, yang akan membentuk kepribadian yang bertanggung jawab, disiplin, serta menjadi pribadi yang baik dalam lingkungan masyarakat, dan menghindari perilaku yang tidak baik, sesuai dengan cara berpikir moral yang telah diberikan.

Kata kunci:pendidikan moral, disiplin, otonomi diri, perilaku anak

\section{Abstract}

Morality is an asset in self development process. Morality has become a universal problem, both in developed or traditional society, since morality damages in a person would disturb another's peace. If there are so many people in society who has damaged morality, the society could be shocked. Morality education for children could change their behavior, thus, when they grow older, they'll become a responsible adult and has respect to the others and capable to meet the 
challenges of the world that rapidly changing. The increase of moral consideration in children which designed through school education could improve the formation of children personality. With the formation of morality consideration, the child would behave in accordance with his or her way of morality thought. Three elements which suggested by Durkheim to become a person with morality are discipline, group attachment, and autonomy. Each individual should have these three elements to be a morality personality. And morality act, in essential, is a central focus in morality world which form a responsible, discipline personality, as well as a good person in society who avoids bad behavior and act in accordance with given morality thought.

Keywords: morality education, discipline, selfautonomy, child behavior

\section{PENDAHULUAN}

Baik dan buruknya suatu bangsa dapat dilihat dari kondisi pemudanya. Jika pemudanya baik, maka baiklah kondisi bangsa tersebut. Sebaliknya, jika pemudanya rusak, maka rusaklah bangsa tersebut. Karena di tangan pemudalah kunci perbaikan suatu bangsa. Merekalah yang akan meneruskan perjuangan generasi terdahulu. Di atas pundak mereka ada tanggung jawab yang berat. Untuk mempersiapkan generasi yang benar-benar mampu mengemban amanah bangsa, maka pendidikanlah merupakan satu-satunya cara yang tepat untuk menggembleng para generasi penerus supaya siap menjadi pemimpin di masa yang akan datang dan mampu memghadapi tantangan globalisasi dan modernisasi. Baik itu melalui lembaga pendidikan formal ataupun non formal (Rajab, 2009:1)

Pendidikan di seluruh dunia kini sedang mengkaji kembali perlunya pendidikan moral atau pendidikan budi pekerti atau pendidikan karakter dibangkitkan kembali. Hal ini bukan hanya dirasakan oleh bangsa dan masyarakat Indonesia, tetapi juga oleh negara-negara maju. Bahkan di negara-negara industri di mana ikatan moral menjadi semakin longgar, masyarakatnya mulai merasakan perlunya revival (kebangkitan kembali) dari pendidikan moral yang pada akhir-akhir ini mulai ditelantarkan (Zuriah, 2007:10)

Salah satu karakter budaya kuat bangsa Indonesia adalah penga- 
malan dan sikap berpegang teguh atas nilai-nilai religiusitas dan moral dalam dimensi kehidupan. Indonesia sejak zaman nenek moyang demikian menjunjung tinggi nilai moral, budaya, agama dan ini terjadi di hampir semua suku bangsa yang tercermin dalam adat istiadat yang mereka lakukan. Cara pandang religius inilah yang menjadi modal dasar pembangunan termasuk dalam pengembangan pendidikan. Perilaku yang bermuatan nilai-nilai keagamaan, keluhuran, moral, kemanusiaan, dan kemasyarakatan menjadi terabaikan karena sukar diukur dan efeknya tidak segera dapat dirasakan sekarang ini. Kondisi seperti di atas, secara tidak langsung merasuk kehidupan generasi muda dan sekolah sebagai bagian dari masyarakat. Sekolah kehilangan "mandat mulia" dari masyarakat untuk diberikan kepada generasi muda. Pendidikan moral, di zaman moderen seperti sekarang ini, agaknya sudah menjadi satu fenomena kemasyarakatan yang boleh dikatakan universal. Hampir semua masyarakat moderen cenderung untuk menempatkan pendidikan moral sebagai bagian integral dari sistem kependidikannya. Kendati demikian tidak lantas berarti bahwa di luar masyarakat modern tidak dikenal adanya pendidikan moral. Praksis pendidikan semacam itu sebenarnya sudah dikenal pula di berbagai tipe masyarakat, termasuk di masyarakat yang tergolong terbelakang sekalipun, yaitu dalam bentuk sosialisasi moral. Minimnya pendidikan moral di Indonesia, mempengaruhi kemajuan Negara Indonesia, salah satunya dikarenakan adanya kecenderungan masyarakat moderen untuk mulai memisahkan kehidupan keagamaannya dari aktivitas hidup kesehari-hariannya (Cheppy H, 1995: 1).

Pendidikan berbasis moral akan sangat berguna bagi peserta didik dalam mengembangkan diri dan bergaul dengan masyarakat. Moral adalah bekal di dalam mengembangkan diri. Hal itu dikarenakan, ketika moral telah diam dalam diri, manusia akan dapat mempertanggungjawabkan segala aktivitasnya terhadap dirinya sendiri, orang lain, dan utamanya kepada Tuhan Yang Maha Esa. Masalah moral, adalah suatu masalah yang menjadi perhatian manusia di mana saja, baik dalam masyarakat yang telah maju, maupun dalam masyarakat yang masih terbelakang. Hal itu dikarenakan, kerusakan moral seseorang 
mengganggu ketentraman yang lain. Jika dalam suatu masyarakat banyak orang yang rusak moralnya, maka akan guncanglah keadaan masyarakat itu. Orang yang pendidikannya tinggi belum tentu mempunyai etika, akhlak dan moralitas yang baik. Malah banyak fakta di lapangan membuktikan betapa banyak orang yang berpendidikan tinggi memiliki kelakuan yang melanggar nilai-nilai kehidupan (agama dan moralitas) dalam bermasyarakat. Artinya bahwa di era globalisasi ini, ilmu tidak lagi mampu mengantarkan kita pada pemahaman agama dengan baik yang dapat terwujud melalui terjaganya akhlak dan moralitas dalam kehidupan sehari-hari (Sahide, 2010: 86).

Sekolah juga perlu melakukan pedagogi kritis. Subyek didik perlu dilatih berpikir kritis. Dalam era teknologi informasi dan komunikasi sekarang ini, tiap hari, melalui berbagai media komunikasi, baik cetak maupun elektronik, kita dibanjiri oleh berbagai informasi dan pesan (termasuk iklan-iklan yang mendorong orang untuk menjadi konsumeris) yang mau mengatakan kepada kita apa yang perlu dilakukan dan apa yang perlu dihindari, apa yang perlu dipercayai serta apa yang perlu dicurigai. Pendidikan nilai kebenaran dan kejujuran, di tengah meluasnya kebohongan publik, di antaranya iklan-iklan konsumeris serta dominasi budaya pasar yang begitu mendewakan nilai uang dan sukses duniawi sampai menghalalkan segala cara untuk dapat cepat kaya, hidup enak dan berkuasa, tentu saja menjadi suatu kegiatan yang melawan arus. Pendidikan bertujuan bukan hanya membentuk manusia yang cerdas otaknya dan trampil dalam melaksanakan tugas, namun diharapkan menghasilkan manusia yang memiliki moral, sehingga menghasilkan warga negara yang baik. Oleh karena itu pendidikan tidak semata-mata mentransfer ilmu pengetahuan kepada peserta didik, tetapi juga mentransfer nilai-nilai moral dan nilai-nilai kemanusiaan yang bersifat universal. Dengan transfer moral bersifat universal, diharapkan peserta didik dapat menghargai kehidupan orang lain tercermin dalam tingkah laku serta aktualisasi diri, semenjak usia SD hingga kelak dewasa menjadi warga negara yang baik (good citizen) (Kusrahmadi, 2007:124)

Dapat dibedakan dua tahap kanak-kanak. Tahap pertama hampir 
seluruhnya berlangsung dalam keluarga atau sekolah taman kanakkanak, yang sebenarnya hanya merupakan perpanjangan peran keluarga. Tahap kedua berlangsung di sekolah, tahap ini sesungguhnya merupakan saat kritis dalam pembentukan sikap moral. Saat di mana perkembangan intelektualnya masih belum sempurna. Kehidupan emosionalnya masih terlalu sederhana dan belum berkembang (Durkheim, dalam Lukas Ginting, 1990 : 13) Masyarakat Indonesia saat ini, kurang memperhatikan moral yang tercermin dari perilaku tidak menghormati nilai-nilai kemanusiaan seperti terjadi tawuran remaja, kurang menghormati orangtua, kurang mentaati norma-norma keluarga, hidup tidak disiplin. Terlebih pada masa globalisasi manusia Indonesia cenderung berperilaku keras, cepat, akseleratif dalam menyelesaikan sesuatu, dan budaya instan. Manusia dipaksa hidup seperti robot, selalu berada pada persaingan tinggi (konflik) dengan sesamanya, hidup bagaikan roda berputar cepat, yang membuat manusia mengalami disorientasi meninggalkan norma-norma universal, menggunakan konsep Machiavelli (menghalalkan segala cara), mementingkan diri sendiri dan tidak memiliki moral yang baik, tidak menghargai, peduli, mengasihi dan mencintai sesamanya (Kusrahmadi, 2007: 117).

Oleh karena itu, sentuhan aspek moral atau akhlak dan budi pekerti menjadi sangat kurang. Demikian pula, sentuhan agama yang salah satu cabang kecilnya adalah akhlak atau budi pekerti menjadi sangat tipis dan tandus. Padahal roda terus berputar dan berjalan, budaya terus berkembang, teknologi berlari sangat pesat, dan arus informasi global bagai tidak terbatas dan tidak terbendung lagi. Sebagai akibatnya adalah budaya luar yang negatif mudah terserap tanpa ada filter yang cukup kuat. Gaya hidup moderen yang konsumeristikkapitalistik dan hedonistik yang tidak didasari akhlak dan budi pekerti yang luhur dari bangsa ini cepat masuk dan mudah ditiru oleh generasi muda. Perilaku negatif, seperti tawuran, anarkis, dan cepat marah menjadi budaya baru yang dianggap dapat mengangkat jati diri mereka. Premanisme ada di mana-mana, emosi meluap-luap, cepat marah dan tersinggung, serta ingin menang sendiri menjadi bagian hidup yang akrab dalam pandangan sebagian dari diri masyarakat sendiri. 
Kenyataan lain juga menunjukkan adanya indikator budi pekerti dan moral yang gersang adalah banyaknya terjadi kasus pelecehan seksual yang dilakukan oleh anak sekolah di bawah umur. Dalam hal ini, bisa saja terjadi pelaku dan korban pelecehan seksual tersebut adalah anakanak yang masih belia. Tindak kejahatan mencuri, menodong, bahkan membajak bus umum pelakunya adalah pelajar sekolah. Hal ini sungguh sangat ironis dan memprihatinkan.

Fenomena dan kenyataan seperti yang dipaparkan tentu tidak boleh dibiarkan berlalu begitu saja. Akan menjadi generasi yang seperti apa kelak jika anak-anak dibiarkan dalam kondisi tersebut. Jika tidak segera dicari jalan keluarnya, maka bangsa ini akan kehilangan generasi atau terjadi lost generation, yang ada adalah generasi yang rusak, tidak bermoral dan tidak berbudi pekerti. Jika generasi kini rusak, lalu bagaimana nasib bangsa ini ke depan. Diberikannya pendidikan moral bagi anak diharapkan dapat mengubah perilaku anak, sehingga peserta didik jika sudah dewasa lebih bertanggung jawab dan menghargai sesamanya dan mampu menghadapi tantangan jaman yang cepat berubah. Di sinilah pentingnya nilai-nilai moral yang berfungsi sebagai media transformasi manusia Indonesia agar lebih baik, memiliki keunggulan dan kecerdasan di berbagai bidang; baik kecerdasan emosional, kecerdasan sosial, kecerdasan spiritual, kecerdasan kinestika, kecerdasan logis, musikal, linguistik, kecerdasan spasial. Peran orangtua (guru) hanya sebatas memberi hal terbaik sesuai dengan jiwa jaman yang sedang dihadapi saat ini, agar kelak peserta didik (anak-anak SD) bagaikan anak panah lepas dari busurnya menentang, mengatasi permasalahannya sendiri, namun memiliki keunggulan moral yang baik dan luhur. Usia sekolah dasar (sekitar umur 6 - 12 tahun), ini merupakan tahapan penting bagi perkembangan seorang peserta didik, bahkan suatu hal yang fundamental bagi kesuksesan perkembangan pendidikan selanjutnya. (Kusrahmadi, 2007:120).

Maka sangat dibutuhkan sekali pendidikan moral sejak dini, karena sesuai dengan pendapat Emile Durkheim, bahwa apabila tahap kanak-kanak pada masa sekolahnya itu berlalu, belum diletakkan dasar-dasar moralitas, maka dasar-dasar moralitas itu tidak akan per- 
nah tertanam dalam diri si anak (Durkheim, dalam Lukas Ginting 1990 :13). Bagi Durkheim, sekolah mempunyai fungsi yang sangat penting dan sangat khusus; untuk menciptakan makhluk baru, yang dibentuk sesuai dengan kebutuhan masyarakat. Durkheim mencoba mengerti kebutuhan anak khususnya dalam hal pendidikan moral, bagaimana metode yang digunakan kepada anak, sehingga anak didik mampu memahami serta menerima pendidikan moral ini. Durkheim sebagai pemikir sosiolog dan filsuf, perhatiannya sudah penuh tercurahkan pada moralitas. Hubungan sosial dengan "moral" merupakan benang merah yang selalu tampak jelas dalam tulisan-tulisannya. Moralitas merupakan fakta sosial yang khas. Berdasarkan latar belakang di atas, beberapa masalah yang hendak dikaji penulis dalam penelitian ini adalah: a) Bagaimanakah konsep pendidikan moral menurut Emile Durkheim? b) Bagaimanakah konsep pendidikan moral anak di Indonesia? c) Bagaimanakah relevansi konsep pendidikan moral Emile Durkheim dalam menyoroti pendidikan moral anak di Indonesia?

\section{PROBLEMATIKA DAN URGENSI PENDIDIKAN MORAL ANAK SAAT INI}

Sistem pendidikan Nasional menyisakan keterpurukan di sektor pendidikan, membentuk SDM yang sarat dengan ilmu pengetahuan: kaya ilmu, intelektual, berwawasan dan menciptakan manusia superior. Dengan kata lain, sistem pendidikan kita selama ini lebih menitikberatkan dan menjejalkan pada penguasaan kognitif akademis. Sementara afektif dan psikomotorik seolah-olah dinomorduakan. Apa yang terjadi? Terbentuknya pribadi yang miskin tata krama, sopan santun, dan etika moral (Isjoni, $2006: 111$ ).

Sistem Pendidikan Nasional di Indonesia sebagaimana tertuang dalam Undang-Undang No.2/89 Sistem Pendidikan Nasional dengan tegas merumuskan tujuannya pada Bab II, Pasal 4 yang berbunyi: Mengembangkan manusia Indonesia seutuhnya. Manusia Indonesia seutuhnya yang dimaksud antara lain bercirikan, beriman dan bertakwa kepada Tuhan Yang Maha Esa dan berbudi pekerti luhur, memiliki pengetahuan dan keterampilan, sehat jasmani dan rohani, kepribadian 
yang mantap dan mandiri, serta rasa tanggung jawab kemasyarakatan dan kebangasaan. Tujuan tersebut sebenarnya sudah sangat lengkap untuk mendidik anak didik kita menjadi pribadi yang utuh dan mandiri dilandasi akhlak dan budi pekerti yang luhur, namun sepertinya sentuhan aspek moral sangatlah kurang. Sebagai akibatnya adalah budaya luar yang negatif mudah terserap tanpa ada filter yang cukup kuat. Gaya hidup yang konsumeristik-kapitalistik dan hedonistik yang tidak didasari akhlak dan budi pekerti yang luhur dari bangsa ini cepat masuk dan mudah ditiru oleh generasi muda. Ditunjukkan adanya indikator budi pekerti dan moral yang gersang yaitu, banyaknya terjadi pelecehan seksual yang dilakukan oleh anak sekolahan di bawah umur. Dalam hal ini bisa saja terjadi pelaku dan korban pelecehan seksual tersebut adalah anak-anak yang masih belia. Hal ini sungguh sangat ironis dan memprihatinkan (Zuriah, 2003: 159-160).

Gaya hidup konsumtif, ingin cepat kaya dengan jalan pintas, dengan menabrak kiri-kanan, menipisnya kesetiakawanan sosial dan sebagainya merupakan gejala yang hampir-hampir dianggap lumrah saja oleh sebagian besar masyarakat kita yang justru status ekonominya jauh lebih baik dari golongan masyarakat yang lain. Jika indikasi ini benar, lalu apa yang tidak tepat dalam sistem pengajaran moral kita? Orang boleh bersilang pendapat dalam menganalisa masalah ini. Yang jelas, himpitan ekonomi bukan lagi menjadi satu-satunya penyebab melemahnya disiplin nasional (Abdullah, 1992:24).

Moral bangsa ini sudah hancur ketika penguasa, guru dan siswa tidak lagi hidup berdampingan. Mereka justru melakukan tindakantindakan yang cenderung mengarah pada tindakan amoral. Hal ini terbukti dengan banyak hal yang terjadi, seperti yang telah dipaparkan di atas, ditambah lagi pendidikan yang tidak memihak kaum kecil, moralitas pelajar yang semakin hancur, dan pendidikan yang antirealitas sosial. Pelajar sebagai pewaris kehidupan bangsa ternyata banyak yang tidak dapat diharapkan. Mereka banyak disibukkan dengan hal-hal yang kurang bermanfaat bagi diri, keluarga, bangsa dan negara, seperti berkumpul membicarakan hal-hal yang kurang bermanfaat, tawuran, merokok hingga mengkonsumsi narkoba. Bercermin dari hal tersebut, 
sepertinya ada ketidakberesan dalam sistem pendidikan kita. Ternyata pendidikan belum menyentuh aspek moral. Karena itu, tidak aneh jika di negeri ini banyak terjadi bentuk KKN (Kolusi, Korupsi, dan Nepotisme) yang dilakukan orang-orang berpendidikan yang mempunyai gelar akademis. Karena pendidikan sekarang diformat instan (siap pakai), akhirnya menjadi seperti buruh-buruh pabrik. Pendidikan tidak diarahkan untuk menciptakan tenaga-tenaga profesional yang membuka lapangan pekerjaan sendiri. Bangunan pemikiran pelajar hanya dipola tidak lebih bagaimana setelah lulus sekolah mendapatkan pekerjaan di tempat tempat yang bonafid (Setiawan, 2006 :59-61).

Dengan demikian dapat dipahami bahwa perilaku dan tindak amoral disebabkan oleh moralitas yang rendah. Moralitas yang rendah disebabkan oleh pendidikan moral di sekolah yang kurang efektif. Untuk itu ditekankan bahwa peranan guru dan pendidikan moral di sekolah lebih diintensifkan. Dan mengenai urusan kebobrokan moral tidak bisa diperbaiki hanya dengan imbauan, pidato, khotbah, sandiwara, seminar, rapat kerja, dan berbagai bentuk upaya jenis lainnya, melainkan harus dengan ketepatgunaan pendidikan moral di sekolah (Sjarkawi, 2006: 45).

Disebabkan oleh pengaruh globalisasi yang ditunggangi oleh semangat fundamental pasar, pendidikan tidak lagi sepenuhnya dipandang sebagai upaya mencerdaskan bangsa atau suatu proses pemerdekaan manusia, tetapi mulai bergeser menuju komodikasi pendidikan. Karena komodikasi pendidikan terjadi dua perubahan orientasi dalam pendidikan nasional. Pertama peranan negara untuk mencerdaskan semakin dikurangi dan digantikan oleh peranan pasar. Kedua, tujuan pendidikan nasional mulai dari tingkat dasar sampai tinggi tidak lagi untuk mencerdaskan kehidupan bangsa, tetapi lebih terfokus untuk menghasilkan lulusan yang menguasai scientia, walaupun belum sepenuhnya sesuai dengan kebutuhan bangsa, tetapi kurang membekali peserta didiknya dengan semangat kebangsaan, semangat keadilan sosial, serta sifat-sifat kemanusiaan dan moral luhur sebagai warga negara (Saksono, 2010:76).

Problematika moral tentunya berkisar, bagaimana peran orang- 
tua, sekolah dan masyarakat dalam membangun generasi bermoral. Namun tidak menutup kemungkinan minimnya pendidikan moral terjadi ketika dapat kita lihat persentase jumlah anak yang ada di Indonesia sekitar 12 persen yang dapat mengikuti program wajib belajar. Selebihnya mereka tidak memperoleh kesempatan belajar yang selayaknya. Dari kondisi ini dapat dibayangkan jumlah yang tersisa masih sekitar 88 persen justru menjadi pekerja anak untuk membantu ekonomi keluarga. Jika mereka terlalu sering membantu orang tua untuk memenuhi kebutuhan keluarga, berarti mereka sendiri tidak mempunyai kesempatan belajar di rumah, khususnya belajar penanaman nilai-nilai budi pekerti yang luhur. Akibat tuntutan kebutuhan hidup keluarga sangat mendesak jangankan memberi pendidikan bagi anak, masalah kesehatan dan keselamatan kerja bagi anak pun menjadi hal yang diabaikan orang tua. Orang tua tidak peduli jika anaknya dieksploitasi dengan upah yang sangat murah, bahkan yang lebih parah, orang tua justru kadang melanggar HAM anak dengan menyiksa anak kandung sendiri jika bekerja tidak mencapai target (Zuriah, 2007: 162).

Persoalan yang menarik dalam konteks penumbuhkembangan nilai-nilai moral bagi anak bahwa penumbuhkembangan nilai-nilai moral pada anak didik ternyata tidak hanya sebatas mengupayakan dan menciptakan bentuk-bentuk interaksi sosial yang sangat kondusif dan positif bagi tumbuh kembangnya nilai-nilai moral dalam kehidupan anak yang akhirnya bermuara pada perilaku moral dalam kehidupan keseharian mereka. Namun yang juga sama pentingnya, bahkan lebih penting dan memiliki arti yang amat strategis dari yang pertama, adalah menciptakan kemampuan bagi anak-anak didik secara cerdas mampu memahami dan menemukan nilai-nilai moral dalam dinamika interaksi sosialnya yang penuh dengan tantangan dan tamparan moral, terutama pada kondisi-kondisi sosial yang dinilai tidak kondusif bagi penumbuhkembangan nilai-nilai moral. Kendatipun diakui bahwa nilai-nilai moral itu pada lazimnya tumbuh dan berkembang didasarkan atas norma-norma dan aturan-aturan yang berlaku secara universal di tengah-tengah masyarakat tetapi juga mesti diakui bahwa problematika moral juga tumbuh selain dari perkembangan internal 
psikis dan fisik yang tengah berlangsung pada diri anak, juga stimuli dinamika interaksi sosial anak dengan lingkungan di luar dirinya. Bahkan untuk yang terakhir ini pada masa tertentu lebih mendominasi penumbuhkembangan nilai-nilai moral anak dan tidak jarang akan menenggelamkan nilai-nilai moral yang telah dimiliki anak pada masa-masa sebelumnya, atau bentuk perilaku menyimpang lainnya. Berkaitan dengan perkembangan psiko-sosial anak, John Dewey juga berpendapat bahwa anak akan menjadi lebih bermoral ketika ia telah mampu menilai situasi yang didahului oleh kemampuannya berperilaku sesuai dengan standar masyarakat atau kelompoknya. Begitu pula anak akan menjadi lebih rasional ketika ia telah berperilaku berdasarkan kebutuhan-kebutuhan fisiknya (Amril, 2006:13-14).

Pada dasarnya moralitas merupakan bagian yang tidak dapat dipisahkan dalam pengembangan eksistensialitas manusia, bahkan tidak berlebihan untuk dikatakan bahwa eksistensialitas manusia itu pada prinsipnya adalah moralitas, sedemikian rupa dari perspektif ini dapat dikatakan pula moralitas merupakan inti dari eksistensialitas manusia. Apabila kita ajukan pertanyaan kepada orang tua, apakah anak-anak perlu dipengaruhi melalui pendidikan moral?. Umumnya mereka akan merespon dengan positif, dalam artian setuju sepenuhnya. Apabila pertanyaan yang sama kita ajukan kepada guru-guru yang berpengalaman, maka jawaban senada juga akan kita peroleh, dalam artian tidak ada kesangsian sedikitpun tentang perlunya setiap orang memiliki wawasan moral (Cheppy Haricahyono, 1995 : 201).

Esensi mengapa pendidikan moral perlu dikedepankan? Adanya panutan nilai, moral, dan norma dalam diri manusia dan kehidupan akan sangat menentukan totalitas diri individu atau jati diri manusia, lingkungan sosial, dan kehidupan individu. Oleh karena itu, pendidikan nilai yang mengarah pada pembentukan moral yang sesuai dengan norma-norma kebenaran menjadi sesuatu yang esensial bagi pengembangan manusia utuh dalam konteks sosialnya. Ini mengingat bahwa dunia afektif yang ada pada setiap manusia harus selalu dibina secara berkelanjutan, terarah, dan terencana sehubungan dengan sifatnya yang labil dan kontekstual. Sasaran pendidikan nilai pada umumnya 
dapat diarahkan untuk (a) membina dan menanamkan nilai moral dan norma, (b) meningkatkan dan memperluas tatanan nilai keyakinan seseorang atau kelompok, (c) meningkatkan kualitas diri manusia, kelompok atau kehidupan, (d) menangkal, memperkecil dan meniadakan hal-hal yang negatif, (e) membina dan mengupayakan terlaksananya dunia yang diharapkan (the expected world), (f) melakukan klarifikasi nilai intrinsik dari suatu nilai moral dan norma dan kehidupan secara umum. Untuk dapat melakukan pendidikan moral tidak hanya terbatas pada lingkungan sekolah oleh guru saja. Pendidikan moral dapat dilakukan oleh siapa saja, kapan saja, dan dimana saja. Meskipun demikian, umumnya disebut tiga lingkungan yang amat kondusif untuk melaksanakan pendidikan moral, yakni lingkungan keluarga, lingkungan pendidikan, dan lingkungan masyarakat.

Merebaknya tuntutan tentang pentingnya pendidikan moral (budi pekerti) di lingkungan persekolahan, haruslah diakui berkaitan erat dengan semakin berkembangnya pandangan dalam masyarakat luas bahwa pendidikan nasional dalam berbagai jenjang, khususnya jenjang menengah dan tinggi telah gagal dalam membentuk peserta didik yang menilai akhlak, moral dan budi pekerti yang baik. Lebih jauh lagi, banyak peserta didik sering dinilai tidak hanya kurang memiliki kesantunan baik di sekolah, di rumah, dan lingkungan masyarakat, tetapi juga sering terlibat dalam tindak kekerasan massa seperti tawuran dan sebagainya (Zuriah, 2007:112).

Pengaruh pentingnya pendidikan moral di Indonesia memiliki jangka yang amat panjang, apalagi ketika pendidikan moral telah ditanamkan sejak dini, sejak usia anak mengenal manusia satu dan lainnya, serta ketika belajar mengenal lingkungan sekitar. Memahami pentingnya pendidikan moral bagi peserta didik (anak) melalui fungsi dan kegunaannya berdasarkan Draf Kurikulum Berbasis Kompetensi (2001) adalah sebagai berikut (Zuriah, 2007: 104-105):

a. Pengembangan, yaitu untuk meningkatkan perilaku yang baik bagi peserta didik yang telah tertanam dalam lingkungan keluarga dan masyarakat.

b. Penyaluran, yaitu untuk membantu peserta didik yang memiliki 
bakat tertentu agar dapat berkembang dan bermanfaat secara optimal sesuai dengan budaya bangsa.

c. Perbaikan, yaitu untuk memperbaiki kesalahan, kekurangan dan kelemahan peserta didik dalam perilaku sehari-hari.

d. Pencegahan, yaitu mencegah perilaku negatif yang tidak sesuai dengan ajaran agama dan budaya bangsa.

e. Pembersih, yaitu untuk membersihkan diri dari penyakit hati seperti egois, iri, dengki, agar anak didik tumbuh dan berkembang sesuai dengan ajaran agama dan budaya bangsa.

f. Penyaring (filter), yaitu untuk menyaring budaya bangsa sendiri dan budaya bangsa lain yang tidak sesuai dengan nilai-nilai budi pekerti.

Pada dasarnya tujuan pendidikan moral di sekolah membantu siswa mempertinggi tingkat pertimbangan, pemikiran, dan penalaran moralnya. Tingkat pemikiran dan pertimbangan moral terbukti secara empiris dapat ditingkatkan melalui pendidikan moral (Sjarkawi, 2006: 51).

Sekolah adalah salah satu lembaga yang bertanggung jawab terhadap pembentukan karakter pribadi anak (character building), karenanya di sini peran dan kontribusi guru sangat dominan. Sebagai suatu lembaga, sekolah memiliki tanggung jawab moral bagaimana anak didik itu menjadi pintar dan cerdas sebagaimana diharapkan oleh orangtuanya. Akan tetapi kadang-kadang guru lupa, bahwa ada satu sisi yang terlupakan, yakni unsur mendidik. Apalah artinya seorang anak didik pintar dan cerdas, tetapi tidak memiliki hati nurani, angkuh dan sombong, dan menganggap orang lain tidak ada apa-apanya. Jika dicermati secara seksama, hakiki dari sistem pendidikan kita diharapkan menghasilkan keluaran kesejahteraan lahir dan batin, terbentuknya manusia yang beriman dan bertakwa kepada Tuhan Yang Maha Esa, berakhlak mulia, berbudi pekerti luhur, sejahtera lahir dan batin, terampil dan memiliki jiwa kebangsaan. Sungguh mulia sebenarnya harapan dari kebijakan pendidikan nasional, jika benar-benar tercapai, maka tidak salah kiranya, sebagai pewaris dan penerus pembangunan nasional, anak didik dipersiapkan menjadi pemegang kendali tongkat 
estapet pembangunan ke depan (Isjoni, 2006:111-112).

Berkaca dengan kondisi yang pernah kita alami seharusnya makin menggugah kesadaran kita betapa pentingnya pendidikan moral bagi anak-anak dan betapa bahayanya mengabaikan pendidikan moral. Untuk itu, pendidikan moral perlu diarahkan menuju upaya-upaya terencana untuk menjamin moral anak-anak yang diharapkan menjadi warga negara yang cinta akan bangsa dan tanah airnya, dapat menciptakan dan memelihara ketenteraman dan kerukunan masyarakat dan bangsa di kemudian hari. Jalan panjang yang terutama harus ditempuh adalah memberdayakan pendidikan moral secara intensif di lingkungan keluarga, sekolah dan masyarakat.

\section{PENDIDIKAN MORAL EMILE DURKHEIM}

David Emile Durkheim lahir tanggal 15 April 1858 di Epinal, Prancis, yang terletak di Lorraine. Ia berasal dari keluarga Yahudi Prancis yang saleh, ayah dan kakeknya adalah Rabi. Hidup Durkheim sendiri sama sekali sekuler. Malah kebanyakan dari karyanya dimaksudkan untuk membuktikan bahwa fenomena keagamaan berasal dari faktor-faktor sosial dan bukan ilahi. Namun demikian, latar belakang Yahudinya membentuk sosiologinya, banyak mahasiswa dan rekan kerjanya adalah sesama Yahudi, dan seringkali masih berhubungan darah dengannya. Meskipun baru berusia 12 tahun, waktu Perancis kalah perang dari Prusia, pengalaman ini sangat mengesankan baginya dan inilah yang menumbuhkan patriotisme dalam dirinya. Patriotisme bukan dalam arti militer, melainkan kepekaan dan rasa prihatin terhadap dekadensi yang melanda negara dan bangsa Prancis, terutama dalam bidang moral (Muhni, 1994:27).

Dalam filsafat Durkheim, moral memiliki peranan terpenting. Kekangan atau wewenang yang dilakukan oleh kesadaran kolektif jelas terlihat dalam bidang moral. Sesungguhnya fakta-fakta moral itu ada, tetapi ia hanya hidup dalam konteks sosial. Moralitas dalam segala bentuknya tidak dapat hidup kecuali dalam masyarakat. Ia takkan berubah kecuali dalam hubungannya dengan kondisi-kondisi sosial. Dengan kata lain moralitas tidak bersumber pada individu, melainkan 
bersumber pada masyarakat dan merupakan gejala masyarakat (Muhni,1994:36).

Berbeda dengan Durkheim, filsuf moral mempunyai tujuan yang selalu ingin dikejar dan dicapai oleh para filsuf moral yang sepanjang zaman sangat berbeda sifatnya. Sebab mereka tidak mengarah pada suatu tujuan representasi tertentu, tanpa menambah atau mengurangi realitas moral yang ada. Ambisi para filsuf moral seringkali adalah membangun moralitas baru, yakni suatu moralitas yang berbeda dalam tema essensial dengan yang dianut oleh rekan mereka atau para pendahulu. Sedangkan persoalan yang ingin Durkheim bahas ialah bagaimana menemukan kandungan moralitas. Bukan kandungan sebagaimana dipandang oleh filsuf tertentu, tetapi kandungan sebagaimana dipandang oleh kemanusiaan dalam wujud diri kolektif. Dari sudut pandang ini, doktrin-doktrin para filsuf tadi kehilangan sebagian besar nilainya. Jika ilmu moral dan hukum sebagaimana yang sedang kita coba bentuk sudah cukup maju, maka ia akan mampu memainkan peranan yang sama dalam kaitannya dengan fakta moral. Manusia harus menelusuri fakta moral agar dapat menemukan apa sebenarnya fakta moral. Menurut Driyarkarya, manusia itu tidak dari semula mempunyai kesadaran moral. Pada waktu permulaan hidupnya, manusia belum mampu menjalankan kemanusiaannya. Hanya dengan lambat laun dia bertumbuh, kemudian dia bisa berpikir dan berkehendak. Bila manusia sudah dapat berpikir dan berkehendak sendiri, baru dalam taraf perkembangan itulah, dia memasuki dunia moral, artinya barulah dia dapat membedakan antara yang baik dan yang buruk (Driyarkarya, 1966:3).

Durkheim mengatakan lebih lanjut bahwa moralitas dimulai pada kehidupan dalam kelompok, karena hanya disitu ketidakpedulian dan pengabdian mempunyai makna, yang dimaksudkan kehidupan kelompok secara umum yaitu keluarga, perusahaan, kota, bangsa dan organisasi internasional. Kehidupan moral bermula dari keanggotaan dalam suatu kelompok, betapapun kecilnya kelompok itu, sehingga dapat dikatakan bahwa kelompok adalah diri kita sendiri atau bagian terbaik dari diri kita, sebab manusia hanya menjadi manusia sesuai 
dengan tingkat peradabannya (Durkheim dalam Dirdjosisworo, 1989 : 59).

Pandangan filsafat Durkheim yang kedua yaitu realisme, Durkheim mengakui masyarakat sebagai suatu kenyataan. Masyarakat tidaklah transenden dan juga tidak metafisik. Ia adalah (nature)-alamiah. Sifat alamiahnya terdiri atas fakta bahwa ia merupakan pembentuk atau pengelola kebudayaan. Hubungan yang sosial dengan "moral" merupakan benang merah, sehingga dapat dikatakan moralitas merupakan fakta sosial yang khas (Muhni, 94:38).

Pentingnya moralitas terhadap kehidupan manusia dalam masyarakat, berdasarkan pada pandangannya bahwa terdapat dua macam aspek, yaitu aspek objektif dan subjektif yang nampak pada kenyataan atau realita moral. Moralitas objektif terdiri dari aturanaturan dan merupakan moralitas kelompok. Moralitas subjektif bersumber pada individu, yaitu merupakan cara pandang individu moralitas kelompok. Durkheim melihat moralitas kelompok dalam kaitannya dengan setiap peristiwa sejarah tertentu pada setiap manusia dalam masyarakat yang disebutnya mempunyai suatu moralitas yang dijadikan dasar untuk mengaturnya. Setiap kelompok mempunyai moralitas yang didefinisikan dengan jelas. Dengan demikian terdapat moralitas umum yang ditemukan pada setiap individu yang tergantung dalam sebuah kolektivitas. Di samping moralitas umum, menurut Durkheim terdapat moralitas lain yang tidak terhitung jumlahnya, yang terdapat pada kesadaran moral individu. Setiap kesadaran moral individu mengeksplorasikan moral kolektif dengan caranya sendiri. Setiap orang melihat dan menafsirkannya dengan sudut pandang yang berbeda. Hal ini disebabkan karena tidak seorang individu pun yang dapat cocok dengan tepat dengan moralitasnya yang ada pada masanya (Sulistyowati, 1992: 54).

Setiap orang pada momen sejarah tertentu mempunyai suatu moralitas dan atas nama moralitas yang berkuasa inilah pengadilan menghukum dan opini yang menghakimi. Tiap kelompok mempunyai moralitas yang didefinisikan dengan jelas. Moralitas tampil pada kita sebagai suatu himpunan dalil atau himpunan aturan tingkah laku. 
Sanksi adalah konsekuensi suatu tindakan yang tidak timbul dari isi tindakan itu sendiri, tetapi dari pelanggaran aturan yang telah digariskan sebelumnya. Jadi sanksi ada karena adanya aturan yang telah ditentukan sebelumnya, dan pelanggaran merupakan pemberontakan (Durkheim dalam Dirdjosisworo, 1989:46).

Peranan moral yang diteliti Durkheim dalam kedua aspek yaitu moral individu dan moral kelompok bahkan turut menentukan dalam kelangsungan hidup masyarakat karena seperti ditulis oleh Durkheim, moralitas itu memang dibuat oleh masyarakat dan ditujukan untuk masyarakat pula (Durkheim, dalam Lukas Ginting, 1990 : 62). Hal ini berarti masyarakat bukan hanya wahana bagi terwujudnya integrasi sosial yang akan mendukung moralitas, melainkan juga merupakan pangkal dari kesadaran kolektif dan sasaran utama dari perbuatan moral.

Kata moral menurut Magnis Suseno, selalu mengacu pada baikburuknya manusia sebagai manusia, jadi bukan mengenai baik-buruknya begitu saja, Bidang moral adalah bidang kehidupan manusia dilihat dari segi kebaikannya sebagai manusia. Norma-norma moral adalah tolok ukur untuk menentukan betul salahnya sikap dan tindakan manusia dilihat dari segi baik buruknya sebagai manusia dan bukan sebagai pelaku peran tertentu dan terbatas (Suseno, 1987 : 19). Sedangkan moralitas atau etika bagi Durkheim tidak bisa dianggap hanya menyangkut satu ajaran normatif tentang baik dan buruk, melainkan suatu "sistem fakta yang diwujudkan (yang) terkait dalam keseluruhan sistem dunia. Moralitas bukan saja menyangkut sistem perilaku yang sewajarnya, melainkan juga suatu sistem yang didasarkan pada ketentuan-ketentuan. Dan ketentuan ini adalah "sesuatu yang berbeda di luar diri si pelaku". Baginya moralitas bukanlah sesuatu yang deduktif, melainkan sesuatu yang berangkat dari kenyataan empiris. Dengan kata lain moralitas yang ilmiah bercorak pasca pengalaman (Abdullah, 1986 : 9-10). Bahwa pengalaman moral ini tidak dapat dikembalikan pada alam. Ia sependapat dengan aliran naturalis dengan menyampaikan gejala-gejala kemanusiaan seperti kebudayaan, pengetahuan, masyarakat, religi dan moral dalam dunia alam. Jika manusia merupakan anggota alamiah, maka gejala-gejala kemungkinan dapat 
diselidiki secara alamiah dan pada penyelidikan atau studi tentang manusia dan masyarakat dapat diterapkan metode positif (Muhni, 1994: 37). Guna mencegah kekacauan yang timbul sebagai akibat proses perubahan masyarakat, Durkheim menganjurkan untuk memberikan pendidikan moral yang sifatnya sekuler bagi generasi muda. Dengan adanya pendidikan tersebut, maka individualisme yang berlebihan yang timbul akibat berkembangnya masyarakat modern dapat ditangkal. Dengan demikian menurut Durkheim individu akan sadar kewajiban dan keinginan sehingga menjadikannya seorang makhluk yang bermoral (Durkheim dalam Lukas Ginting, 1990:10).

Menurut Durkheim, moral memiliki tiga unsur. Ketiga unsur tersebut saling berkaitan, dan ini menunjukkan bahwa titik berat terletak pada masyarakat dan daya pikir manusia. Unsur- unsur moralitas itu antara lain: semangat disiplin, ikatan pada kelompok-kelompok sosial, otonomi penentuan nasib sendiri.

Pertama, semangat disiplin. Bertindak secara moral berarti menaati suatu norma yang menetapkan perilaku apa yang harus diambil pada suatu saat tertentu, bahkan sebelum dituntut untuk bertindak. Ruang lingkup moralitas adalah ruang lingkup kewajiban. Dan kewajiban adalah perilaku yang telah ditetapkan dalam kaidah tertentu. Bila kita tinjau moralitas sebagaimana adanya, kita akan melihat bahwa moralitas mencakup kaidah-kaidah khusus tertentu dan pasti yang tidak terbilang jumlahnya. Kaidah-kaidah itu mengatur tingkah laku manusia dalam berbagai situasi yang paling sering dihadapinya. Beberapa kaidah dituangkan dalam bentuk undang-undang dan disertai sanksi-sanksi yang jelas. Terlihat jelas bahwa fungsi moralitas pertamatama adalah menentukan tingkah laku, menetapkannya, membatasi unsur yang bersifat semau-maunya saja. Tentu saja isi dari kaidah moral yakni hakikat dari tingkah laku yang diharuskan itu juga mempunyai nilai moral. Pada dasarnya moralitas adalah sesuatu yang bersifat tetap, dan sejauh kita berbicara mengenai jangka waktu yang terlalu panjang, moralitas itu akan tetap sama, tidak berubah. Menurut Durkheim disiplin moral mengajarkan untuk tidak bertindak sesuai dengan keinginan-keinginan yang hanya bersifat sesaat, yang mengakibatkan tingkah laku hanya setaraf dengan kecenderungan-kecen- 
derungan alamiah belaka. Disiplin moral juga mengajarkan bahwa tingkah laku menyangkut adanya usaha yang keras, bahwa suatu tindakan hanya dapat disebut tindakan moral bila dapat mengendalikan kecenderungan-kecenderungan tertentu, menekan keinginan-keinginan tertentu, melunakkan hasrat-hasrat tertentu. Disiplin moral tidak hanya menunjang hidup moral dalam arti sebenarnya, melainkan pengaruhnya berlangsung terus. Bahkan disiplin moral itu berperan besar dalam pembentukan watak dan kepribadian pada umumnya (Abdullah, 1986:178-179).

Disiplin yang dituntut dari anak-anak tidak boleh hanya dilihat sebagai sarana paksaan yang diperlukan bila sudah tidak ada jalan lain untuk mencegah perbuatan yang salah. Disiplin pada dirinya sendiri merupakan faktor pendidikan "sui generis". Hanya melalui disiplin dapat diajarkan kepada anak untuk mengendalikan keinginan-keinginannya, membatasi berbagai macam hasratnya, membatasi dan melalui batasan, menetapkan berbagai sasaran aktivitasnya. Disiplin moral tidak hanya menunjang hidup moral dalam arti sebenarnya, juga pengaruhnya berlangsung terus. Bahkan, peran disiplin moral sangat menentukan dalam pembentukan watak dan kepribadian pada umumnya. Dalam kenyataannya, unsur paling hakiki dari watak adalah kemampuan mengendalikan diri. Untuk pengembangan penguasaan diri itulah diharuskan membina disiplin moral. Disiplin moral mengajarkan bahwa tindakan bersangkut paut dengan usaha keras, bahwa suatu tindakan hanya dapat disebut tindakan moral bila kita mengendalikan kecenderungan-kecenderungan tertentu (Durkheim dalam Lukas Ginting, 1990: 30-31). Jadi disiplin berguna bukan hanya demi kepentingan masyarakat, melainkan juga demi kesejahteraan individu sendiri, melalui disiplin kita belajar mengendalikan keinginan, tanpa ini mustahil orang dapat mencapai kebahagiaannya tinggal disiplin moral sajalah yang masih mampu memberikan pengaruh mengatur tingkah laku manusia.

Pendidikan harus membantu anak untuk memahami sejak dini bahwa untuk mencapai kebahagiaan adalah dengan menentukan sasaran yang dekat dan dapat dicapai sesuai dengan kondisi setiap pribadi. Bila disiplin adalah suatu sarana manusia untuk mewujudkan 
hakikatnya, maka disiplin harus bisa diubah seperti halnya hakikat yang selalu berubah sepanjang zaman, bukan hanya kandungan isi disiplin saja yang berubah, melainkan juga cara bagaimana disiplin ditanamkan dan harus ditanamkan. Bukan hanya lingkup tingkah laku manusia yang berubah, melainkan kekuatan-kekuatan yang membentuk berbagai batasan pun tidak mutlak selalu sama pada berbagai kurun waktu perjalanan sejarah, lebih jauh lagi dapat dikatakan bahwa kekuatan-kekuatan moral akan menjadi pengawal untuk menghadapi kekuatan yang brutal dan ketidaktahuan (Durkheim dalam Lukas Ginting, 1990:38).

Kedua, ikatan pada kelompok-kelompok sosial. Hidup berarti menyesuaikan diri dengan dunia fisik di sekeliling dan dengan dunia sosial di mana kita menjadi anggotanya. Semakin kompleks suatu masyarakat, maka semakin sulit pula moralitas terlaksana secara otomatis. Keadaan lingkungan tidak pernah selalu sama, masyarakat senantiasa berkembang, moralitas sendiri harus cukup fleksibel untuk dapat berubah secara perlahan-lahan. Di luar individu-individu tidak ada sesuatu yang lain selain kelompok-kelompok yang dibentuk dari kesatuan individu-individu, yakni masyarakat. Karena itu tujuan tindakan moral adalah masyarakat. Bertindak secara moral adalah bertindak demi kepentingan bersama. Jika masyarakat dipandang sebagai tujuan tingkah laku moral di dalamnya haruslah kita dapat melihat sesuatu yang lain daripada sekedar penjumlahan individu-individu belaka. Masyarakat itu haruslah merupakan suatu makhluk sui generis (Abdullah, 1986: 192-193).

Menurut Durkheim, manusia pada dasarnya adalah produk masyarakat, dan masyarakat jugalah yang meneruskannya dari satu generasi ke generasi berikutnya. Manusia barulah lengkap jika termasuk dalam beberapa masyarakat, dan secara moralpun barulah lengkap jika merasa dirinya menyatu dengan kelompok yang berbeda-beda di mana ia terlibat: keluarga, perkumpulan, negara dan umat manusia seluruhnya. Pada dasarnya seorang individu dengan hanya mengandalkan kekuatan sendiri, tidak akan bisa mengubah keadaan sosial. Seseorang hanya akan bisa bertindak secara efektif demi kepentingan masyarakat bila menggabungkan usaha-usaha individu sedemikian 
rupa, menghadapi kekuatan sosial dengan kekuatan sosial (Durkheim dalam Lukas Ginting, 1990:58).

Masyarakat bukanlah sekedar wadah bagi terwujudnya integrasi sosial yang akan mendukung solidaritas, melainkan juga merupakan pangkal dari kesadaran kolektif dan sasaran utama dari perbuatan moral. Durkheim tidak bisa membayangkan perbuatan moral yang terlepas dari ikatan sosial. Manusia dalam kesendiriannya terlepas dari masalah moralitas. Karena itu moralitas, bukanlah sekedar kategori imperatif seperti yang disebut Kant, melainkan juga dan terutama merupakan keinginan yang rasional (saya mau berbuat moral karena akal saya mengatakan demikian). Perbuatan moral bukanlah sekedar kewajiban yang tumbuh dari dalam diri, melainkan juga "kebaikan" ketika diri telah dihadapkan dengan dunia sosial. Maka moralitas bagi Durkheim terikat erat dengan keteraturan perbuatan dan otoritas. Suatu tindakan bisa disebut moral, kalau tindakan itu tidak menyalahi kebiasaan yang diterima dan didukung oleh sistem kewenangan otoritas sosial yang berlaku. Sedangkan tujuan dari tindakan moral itu tentu saja demi kepentingan kolektif dan demi keterikatan pada kelompok. Inilah yang membedakan moralitas dengan "keperluan" yang bersifat individual (Abdullah, $1986: 17)$.

Ada beberapa tujuan tertentu yang memberi sifat moral pada tindakan-tindakan manusia. Tindakan-tindakan yang selalu tertuju pada keuntungan pribadi, tidaklah memiliki nilai moral. Hanya tindakan yang tidak memiliki tujuan pribadi serta berada atas tujuan individual, itulah yang bersifat moral. Tindakan moral hanyalah tindakan yang ditujukan kepada kepentingan kehidupan bersama. Moral baru mulai kalau ia sudah berada dalam suatu kelompok, dan tujuan utama tingkah laku moral dalam artian murni adalah kemanusiaan (Muhni, 1994 : 40).

Ketiga, otonomi atau penentuan nasib sendiri. Kecenderungan kesadaran moral menghubungkan moralitas suatu tindakan dengan otonomi pelakunya adalah suatu kenyataan yang tidak dapat kita kesampingkan dan yang harus kita perhitungkan. Otonomi adalah putusan pribadi yang menyadari sepenuhnya akibat yang bisa ditimbulkan oleh berbagai jenis tindakan. Berhadapan dengan disiplin 
kolektif itu, otonomi berarti suatu kebebasan individual. Untuk bertindak secara moral tidak cukup hanya dengan menghormati disiplin dan terikat pada kelompok. Lebih dari itu, entah karena rasa hormat terhadap kaidah atau karena pengabdian kepada cita-cita kolektif, harus mempunyai pengetahuan, mempuyai kesadaran sejelas dan selengkap mungkin mengenai alasan perbuatan yang dilakukan. Kesadaran tersebut memberikan otonomi kepada tingkah laku, yang untuk selanjutnya dituntut oleh kesadaran umum dari setiap pengada moral yang sejati dan lengkap. Oleh karena itu dapat dikatakan bahwa unsur ketiga moralitas adalah gagasan mengenai moralitas tersebut. Moralitas tidak lagi hanya bertindak secara sukarela, lebih dari itu kaidah yang menyuruh tindakan tersebut haruslah diinginkan secara bebas, yakni diterima dengan suka rela (Abdullah, $1986: 249$ ).

Adanya dualisme dalam kodrat manusia: otonomi adalah produk kehendak yang dituntun oleh nalar, sedangkan heteronomi merupakan perasaan. Kant mencoba memecahkan kontradiksi ini. Hanya ada satu nalar, karena itu bila manusia bertindak berdasarkan nalar, manusia sesungguhnya melakukan tindakan moral dengan kebebasan penuh karena manusia memang sekedar mengikuti hukum dari hakikat penalaran manusia. Agar bisa memahami dunia dan agar bisa mengatur tingkah laku manusia, sebagaimana seharusnya dalam hubungan dengan dunia ini, manusia cukup memikirkan dan menyadari sepenuhnya apa yang ada dalam diri manusia. Menurut Durkheim, pikiranlah yang membebaskan kehendak. Prinsip ini, yang diakui oleh semua orang sejauh menyangkut dunia fisik, juga berlaku bagi dunia moral. Masyarakat merupakan produk kekuatan yang tidak terbilang banyaknya dan manusia hanya merupakan bagian yang sangat kecil. Moralitas itu tidak lain hanyalah apa yang kita inginkan dan kita hanya mampu menaklukan dunia moral dengan cara yang sama sebagaimana kita menaklukan dunia fisik : yaitu dengan membangun ilmu pengetahuan di bidang moral. Dengan demikian dapat kita katakan bahwa unsur ketiga moralitas adalah pengertian mengenai moralitas tersebut (Durkheim dalam Lukas Ginting, 1990: 85-87).

Otonomi kehendak manusia, mencakup pengertian moral dan sangat penting artinya sebagai hasil proses sekularisasi dan kemajuan 
rasionalisme. Menuntut penghargaan bagi pribadi manusia, yang meskipun merupakan produk kehidupan sekelilingnya namun, tidak menjadi budaknya. Kesadaran moral selalu menolak ketergantungan ini, dan menuntut akan kebebasan yang lebih mantap bagi otonomi individu. Semakin besar pengertian manusia tentang moral, tentang sebab-sebab dan fungsinya, semakin bebaslah ia, dan secara sukarela ia akan tunduk pada peraturan-peraturan moral itu. Untuk bertingkah laku susila tidak cukup hanya dengan menghormati disiplin dan terikat kelompok saja. Manusia harus juga memupuk kecerdasannya tentang dasar-dasar dan sebab-sebab tingkah lakunya. Moralitas tidak hanya terdiri atas menjalani perbuatan-perbuatan secara sadar, tetapi harus juga berbuat secara sukarela dan jelas. Disini rasio semakin menjadi unsur penting dari moralitas serta mendidik moral bukanlah berbicara dan juga bukan mengindoktrinasi melainkan menjelaskan (Muhni, 1994:40-41).

Moralitas termasuk unsur manusiawi yang paling utama, karena dengan mendorong manusia untuk mengatasi dirinya sendiri, hal ini justru merangsang manusia untuk menyadari kodratnya sebagai manusia. Manusia dapat dengan mudah memperikirakan hasil-hasil yang bisa dicapai oleh pendidikan berdasarkan konsespi teoretis tersebut. Dari sudut pandang seperti ini cara membina anak di bidang moral bukanlah dengan mengulang-ngulang di mukanya dengan penuh semangat dan penuh keyakinan sejumlah dalil yang sangat umum, yang berlaku kapan saja dan dimana saja, tetapi membuat anak memahami negaranya dan jamannya, mempunyai rasa tanggung jawab, dan mempersiapkannya untuk terjun ke dalam hidup dan dengan demikian membentuknya dan bisa ikut ambil bagian dalam tugas kolektif yang menantinya. Konsepsi moralitas tersebut jelas menuntut sikap tidak mementingkan dirinya sendiri dan dengan jalan melakukan kewajibannya seseorang mencapai suatu kecenderungan yang tidak berlebih-lebihan, yakni pembatasan diri yang merupakan syarat mutlak bagi kebahagiaan dan kesehatan. Demikian pula dengan mengikat diri pada kelompok, maka anak akan dapat ikut ambil bagian dalam hidup yang lebih tinggi yang terdapat dalam kelompok tersebut. Seandainya anak mencoba menutup diri dari dunia luar, memusatkan perhatian- 
nya pada dirinya sendiri, mengarahkan semuanya kepada dirinya sendiri, maka hasilnya adalah kehidupan yang sulit yang bertentangan dengan kodrat alam. Dengan tunduk pada peraturan dan membaktikan diri pada kelompok, maka akan menjadi manusia yang sejati (Durkheim dalam Lukas Ginting, 1990 : 88-89).

Moral juga merupakan pantulan dari masyarakat. Dalam hal ini masyarakat bukan saja merupakan suasana yang melahirkan moralitas, melainkan juga tujuan dari tindakan moral itu. Sebab itulah dalam proses perubahan sosial makin diperlukan adanya pendidikan moral. Pendidikan bukan saja berarti mengajarkan nilai-nilai kepada anakanak, melainkan juga adalah alat untuk menjinakkan hasrat dan dorongan pribadi atau dengan kata lain, alat untuk mendapatkan tumpuan penguasaan diri. Tetapi lebih dari itu, kata Durkheim tujuan utama dari pendidikan moral adalah "untuk melekatkan pada anak-anak perasaan akan harkat manusia". Durkheim juga mengatakan bahwa "Elle cree dans l'homme un etrenouveau" yang artinya pendidikan menciptakan dalam diri manusia sesuatu yang baru" (Durkheim, dalam Lukas Ginting, $1990: 13)$.

\section{RELEVANSI UNSUR-UNSUR MORALITAS EMILE DURKHEIM TERHADAP PENDIDIKAN MORALITAS ANAK DI INDONESIA SAAT INI}

Sekolah mempunyai peranan penting bagi Durkheim untuk menciptakan makhluk baru, yang dibentuk dengan kebutuhan rakyat. Ada tiga unsur yang ditetapkan oleh Durkheim, yang pertama adalah disiplin, yang dibentuk oleh keteraturan tingkah laku, serta wewenang, dan yang kedua adalah keterikatan pada kelompok, kedua unsur ini adalah dua aspek dari satu hal yaitu masyarakat. Disiplin adalah masyarakat yang dilihat sebagai 'ayah', yang memerintahkan dan mendorong untuk melakukan kewajiban. Keterikatan pada kelompok mengimplikasikan masyarakat sebagai 'ibu', citra kebaikan, yang menarik hati. Unsur yang ketiga adalah otonomi, jika perilaku demi kepentingan diri sendiri harus dianggap sebagai amoral, demikian juga halnya dengan perilaku yang mengingkari otonomi pelaku, sebab perilaku yang dibatasi bukanlah perilaku yang baik. Di lain pihak pendi- 
dikan adalah suatu sarana sosial untuk suatu tujuan sosial. Dan guru adalah agen masyarakat, tugas guru adalah menciptakan suatu makhluk sosial, suatu makhluk yang bermoral. Bagi Durkheim, pendidikan menciptakan makhluk baru (Elle cree dans l'homme un etre nouveau) (Durkheim dalam Lukas Ginting, 1990: 9-13).

Namun, makhluk baru di sini, bukan yang jatuh dari langit, tetapi dari masa lampau dan dunianya di masa lampau, seperti yang dikatakan Hardono Hadi, dalam Jati Diri Manusia (1996: 109-110), kepribadian manusia bukanlah sesuatu yang tetap selamanya tanpa menghiraukan perkembangan waktu dan lingkungan, tetapi juga kepribadian inipun selalu dinilai kembali, dirombak, dan dibangun kembali secara baru. Kepribadian manusia selalu berkembang dari masa lampaunya, yang meliputi dirinya sendiri dan dunianya. Dan manusia harus bertanggung jawab terhadap masa depannya karena apa yang dilakukan selalu akan menjadi nilai yang mempengaruhi masa depannya.

Berdasarkan pemahaman kepribadian tersebut, maka anak juga akan mengalami perkembangan dalam dirinya, baik emosional juga pemikirannya, terkadang mereka mencari sesuatu yang sudah berlalu, contohnya rasa ingin tahu tentang asal usul mereka, mereka juga bertindak pada perasaan dan mengekspresikan kepercayaan serta pendapat mereka. Membina anak di bidang moral menurut Durkheim (Lukas Ginting, 1990: 88), bukanlah dengan mengulang-ulang di mukanya dengan penuh semangat dan penuh keyakinan sejumlah dalil yang sangat umum yang berlaku kapan saja dan dimana saja, tetapi membuat dia memahami negara dan zamannya, mempunyai rasa tanggung jawab, dan mempersiapkannya untuk terjun ke dalam hidup dan dengan demikian membentuknya untuk bisa ikut ambil bagian dalam tugas kolektif yang menantinya. Anak juga sebagai pribadi yang bukan hanya makhluk rasional semata-mata melainkan juga makhluk yang memiliki perasaan. Kepribadian mempunyai unsur karakter atau watak. Karakteristik merupakan sifat yang menunjukkan perbedaan atau keunikan perilaku seseorang. Keunikan inilah yang membedakan manusia satu dengan lainnya.

Pembentukan diri merupakan warisan dari masa lampau begitu juga dengan seorang anak didik, ketika membentuk dan mengem- 
bangkan kepribadian mereka dengan kekreativitasan dan keunikan mereka dengan baik sejak dini, maka akan menggambarkan kepribadian mereka kelak di masa dewasa. Dengan tiap unsur pendidikan moral dalam pemikiran Durkheim, ingin disampaikan pula pengaruhnya terhadap pendidikan kepribadian anak, sehingga mendapati kepribadian anak yang disiplin dalam tindakan maupun pikiran mereka, lebih bertanggung jawab atas pemikiran dan tindakan mereka. Kelak mereka pun akan mendapati diri mereka dengan kepribadian yang terus berkembang dalam kehidupan masyarakat yang terus berkembang sesuai zamannya, tentunya sebagai pribadi yang berguna bagi bangsa dan negara, mempunyai pribadi yang produktif, bukan hanya menjadi pribadi yang dapat dibanggakan oleh diri sendiri. Sama halnya seperti yang dikatakan oleh Hardono Hadi, bahwa ciri khas manusia adalah sifat kreatifnya yang begitu produktif di dalam menciptakan sesuatu yang baru. Pembaharuan yang dihayati secara pribadi, kemudian ditawarkan kepada masyarakat, sehingga masyarakat pun tidak mandul, melainkan bergerak maju dengan seluruh daya kreatifnya (Hardono Hadi, 1996 :124).

Akhir-akhir ini dapat dilihat fenomena yang cukup menarik, yaitu keadaan bangsa yang semakin tidakjelas arah tujuannya. Bangsa ini semakin hancur karena tekanan banyak pihak baik dari dalam maupun luar negeri. Konflik horizontal tidak kunjung usai, ditambah lagi dengan hancurnya moralitas masyarakat yang ditandai dengan merebaknya tawuran pelajar, serta narkoba di kalangan pelajar. Bangsa ini benar-benar kehilangan keperkasaan sebagai bangsa besar. Moral bangsa ini sudah hancur, ketika penguasa, guru dan siswa tidak lagi hidup berdampingan. Mereka justru melakukan tindakan-tindakan yang cenderung mengarah pada tindakan-tindakan yang amoral. Hal ini terbukti dengan banyaknya hal yang terjadi sekarang, seperti moralitas pelajar yang semakin hancur, dan pendidikan yang antirealitas sosial (Setiawan, 2006:58).

Merebaknya tuntutan tentang pentingnya pendidikan moral (budi pekerti) di lingkungan persekolahan, haruslah diakui berkaitan erat dengan semakin berkembangnya pandangan dalam masyarakat luas bahwa pendidikan nasional dalam berbagai jenjang, khususnya jen- 
jang menengah dan tinggi telah gagal dalam membentuk peserta didik yang menilai akhlak, moral dan budi pekerti yang baik. Lebih jauh lagi, banyak anak didik sering dinilai tidak hanya kurang memiliki kesantunan baik di sekolah, di rumah, dan lingkungan masyarakat, tetapi juga sering terlibat dalam tindak kekerasan massa seperti tawuran (Zuriah, 2007: 112).

Ini adalah bukti ketidakberhasilan sekolah untuk membentuk anak menjadi manusia pembelajar. Pembelajar adalah individu-individu yang dapat memilah dan memilih mana yang baik dan yang buruk. Maka dari itu, bagaimana sekarang memposisikan proses pembelajaran sebagai hal yang suci dan sesuai dengan harapan masyarakat, yaitu sebuah pembelajaran yang tidak menindas dan juga tidak tertindas. Selama ini dapat dilihat penindasan justru lahir dari dunia pendidikan.

Benny Setiawan dalam bukunya Manifesto Pendidikan Di Indonesia, (2006: 28), memaparkan kekerasan yang dilakukan oleh oknum guru di beberapa daerah bermunculan. Banyak kalangan yang beranggapan, beberapa kasus kekerasan yang dilakukan oleh oknum guru tersebut, didasarkan oleh keberadaan sekolah yang sudah menjadi bagian tak terpisahkan dari industrialisasi. Dengan demikian kedaulatan guru tercabut dari akarnya dan menjadikan guru tidak memiliki kemampuan untuk bertindak sebagaimana tugasnya: membimbing, mengarahkan, dan membina. Dilema hilangnya kedaulatan guru dan carut marutnya sistem pendidikan nasional adalah pekerjaan berat bagibangsa Indonesia.

Dikutip dari Jawa Pos, 02 Mei 2005, kekerasan terhadap siswa yang terjadi di SMP Negeri 32 Semarang dan pemukulan seorang peserta les di Pangkal Pinang, serta seorang guru SMK Karya Nugraha Boyolali, memukul siswa hingga dirawat inap, karena mengalami luka yang amat serius, yang bermula dari keterlambatan siswa mengambil kartu ujian, sehingga guru melayangkan 20 pukulan versi orangtua, namun 3 kali pukulan menurut pengakuan guru tersebut (Setiawan, 2006:30).

Padahal menurut Durkheim, guru adalah pusat di sekolah, yang memiliki otoritas moral yang dibarengi dengan sikap percaya dan mampu, totalitas dalam berusaha, dan dalam mengajar, perlu diperha- 
tikan totalitas kepribadian peserta didik secara lebih fundamental. Adanya hukuman fisik di sekolah yang secara moral jelas tidak diperkenankan tidak mempunyai suatu cara apapun untuk memperhalusnya, inilah sebabnya mengapa hal itu harus dihindari. Maka lebih lanjut otoritas guru harus diperlembut dengan kebajikan agar ketegasan tidak merosot menjadi kekasaran atau kekerasan.

Pendidikan moral akan berhasil apabila, guru memberi stimulus agar anak memberi respon sesuai dengan keinginan pendidik, dan dengan stimulus, respon itu anak diberi classical conditioning untuk menciptakan kondisi belajar yang lebih kondusif. Agar tujuan pendidikan moral dapat tercapai, guru dapat memberi hadiah kepada anak yang berhasil dan hukuman bagi yang gagal, namun dalam koridor memanusiakan manusia. Proses stimulus dan respon dalam pendidikan moral harus diberikan terus menerus dan terprogram, sehingga anak akan memiliki habitus (pendidikan yang merubah perilaku) dalam mewujudkan manusia Indonesia yang bermoral.

Pada dasarnya tujuan pendidikan moral di sekolah membantu anak mempertinggi tingkat pertimbangan, pemikiran, dan penalaran moralnya. Tingkat pemikiran dan pertimbangan moral terbukti secara empiris dapat ditingkatkan melalui pendidikan moral. Sebagai suatu lembaga, sekolah memiliki tanggung jawab moral bagaimana anak itu menjadi pintar dan cerdas sebagaimana diharapkan oleh orang tuanya. Akan tetapi kadang-kadang guru lupa, bahwa ada satu sisi yang terlupakan, yakni unsur mendidik. Apalah artinya seorang anak pintar dan cerdas, tetapi tidak memiliki hati nurani, angkuh dan sombong, dan menganggap orang lain tidak ada apa-apanya.

Dengan demikian dapat dipahami bahwa perilaku dan tindak amoral disebabkan oleh moralitas yang rendah. Moralitas yang rendah disebabkan oleh pendidikan moral di sekolah yang kurang efektif. Untuk itu ditekankan bahwa peranan guru dan pendidikan moral di sekolah lebih diintensifkan. Dan mengenai urusan kebobrokan moral tidak bisa diperbaiki hanya dengan imbauan, pidato, khotbah, sandiwara, seminar, rapat kerja, dan berbagai bentuk upaya jenis lainnya, melainkan harus dengan ketepatgunaan pendidikan moral di sekolah (Sjarkawi, 2006:45-51). 
Sehingga Durkheim menganggap bahwa bangsa harus menggantungkan harapan yang besar kepada guru. Hal ini bukan hanya karena pendidikan-pendidikan intelektual yang dapat ia berikan, namun adanya kesempatan yang tiada taranya untuk menanamkan semacam pengaruh pada anak yang tidak dapat digantikan oleh apapun (Durkheim dalam Lukas Ginting, 1990:173).

Setiap tanggal 23 Juli diperingati sebagai hari anak. Peringatan ini sudah seharusnya dijadikan refleksi bersama bagi keluarga guna menghindari tindakan kekerasan terhadap anak dan pemenuhan hakhak dasarnya. Biasanya memperingatinya dengan ditandai penyalaan lampu kendaraan bermotor jam 12.00-14.00. Namun, setiap perayaan hari anak, terdapat persoalan yang begitu memprihatinkan, yakni persoalan penyalahgunaan obat-obatan terlarang yang dilakukan generasi muda. Sekitar 3,2 juta rakyat Indonesia diindikasikan menggunakan narkoba, sekitar 1280 jiwa telah terenggut nyawanya. Data di atas membuat kita prihatin. Artinya generasi penerus cita-cita dan perjuangan bangsa Indonesia telah teracuni dengan barang haram. Kecenderungan ini diakibatkan oleh sikap pergaulan bebas yang kebablasan. Jika usia muda telah terjebak kepada hal-hal yang merugikan diri sendiri, keluarga dan lingkungan, bagaimana mungkin dapat menatap masa depan dengan baik. Masa depan yang suram menjadi momok bagi masyarakat (Setiawan, 2006: 54). Kecenderungan untuk hidup bebas tanpa pengawasan ini sering menjadi alasan generasi muda untuk mencari jati diri, kurangnya kepedulian orangtua, inilah yang seharusnya diingat oleh masyarakat modern, ketika orangtua sama sekali tidak lagi mempunyai otoritas dalam membina anaknya, ia akan lebih banyak bergaul dengan lingkungan yang kurang baik.

Menurut Durkheim, dalam Pendidikan Moral (1990: 39), terjemahan Lukas Ginting, bahwa manusia sebagai makhluk terbatas, secara fisik merupakan bagian dari alam semesta, secara moral merupakan bagian dari masyarakat. Semakin kompleks suatu masyarakat, semakin sulit pula bagi moralitas untuk bisa terlaksana berdasarkan mekanisme otomatik. Keadaan lingkungan tidak pernah sama, karena itu sebagai akibatnya, dalam penerapan moralitas diperlukan pemahaman intelektual. Karena masyarakat senantiasa berkembang, moralitas 
sendiri harus cukup fleksibel untuk dapat berubah secara perlahanlahan jika diperlukan. Dalam menyesuaikan diri semua individu harus menyadari apa yang mereka lakukan. Lebih dari itu penyesuaian itu tidak boleh dipaksakan, sehingga manusia kehilangan kesadaran intelektualnya. Karena itu anggapan bahwa disiplin itu perlu, tidak berati bahwa disiplin mengandaikan perlunya ketaatan buta dan tunduk seperti budak. Namun orang yang hidup tidak teratur, orang yang tidak mengenal disiplin, adalah orang-orang yang dari segi moral tidak lengkap.

Pendidikan bertujuan bukan hanya membentuk manusia yang cerdas otaknya dan trampil dalam melaksanakan tugas, namun diharapkan menghasilkan manusia yang memiliki moral, sehingga menghasilkan warga negara excellent. Oleh karena itu pendidikan tidak semata-mata mentransfer ilmu pengetahuan kepada peserta didik, tetapi juga mentransfer nilai-nilai moral dan nilai-nilai kemanusiaan yang bersifat universal. Dengan transfer moral bersifat universal, diharapkan anak didik dapat menghargai kehidupan orang lain, tercermin dalam tingkah laku serta aktualisasi diri.

Pendidikan merupakan kumpulan teori yang karenanya ia dekat dengan ilmu. Akan tetapi teori ilmiah hanya mempunyai satu tujuan yakni pengungkapan realitas, sedangkan teori pendidikan mempunyai tujuan yang jelas yakni menuntun perilaku. Durkheim lebih lanjut menegaskan bahwa, agar dapat memahami dunia, dan agar bisa mengatur tingkah laku sebagaimana seharusnya dalam hubungan dengan dunia itu, cukup memikirkan masak-masak dan menyadari sepenuhnya apa yang ada dalam diri. Dalam hal moralitas, cita-cita yang digariskan merupakan perpaduan yang sangat mengagumkan antara sikap tunduk dan kuasa, antara kepatuhan dan otonomi. Jika mencoba memberontak terhadapnya, maka dengan keras diingatkan mengenai pentingnya aturan. Jika menyesuaikan diri terhadapnya maka ia membebaskan dari kepatuhan itu dengan membiarkan nalar mengatur peraturan yang memaksa itu (Durkheim, dalam Lukas Ginting, 1990: 89).

Melihat sedikit ke belakang mengenai tahap masa anak-anak menurut Durkheim, tahap pertama hampir seluruhnya berlangsung dalam keluarga, dan tahap kedua berlangsung di sekolah dasar. Dan 
pembahasan mengenai pendidikan moral, akan memusatkan perhatian pada tahap yang kedua, karena tahap ini merupakan tahap kritis dalam pembentukan sikap moral, dan jika tahap kedua ini berlalu, yakni sesudah masa sekolah, belum diletakkan dasar-dasar moralitas, maka dasar-dasar moralitas itu tidak akan pernah tertanam dalam diri anak. Maka di Indonesia sebaiknya menanamkan pendidikan mengenai moral sejak dini kepada anak.

Berbicara pendidikan sekolah, sama halnya berbicara mengenai kehidupan. Pendidikan merupakan proses yang dilakukan setiap individu menuju ke arah yang lebih baik sesuai dengan potensi kemanusiaan. Driyarkara merumuskan pendidikan sebagai memanusiakan manusia muda, membentuk manusia muda untuk berkembang menjadi manusia utuh, bermoral, bersosial, berkepribadian, dan berpengetahuan. Sama halnya pendidikan yang menciptakan makhluk baru menurut Durkheim. Sekolah menyerupai masyarakat politik. Lingkungan sekolah merupakan asosiasi yang lebih luas daripada keluarga atau teman-teman. Lingkungan sekolah tidak berasal dari hubungan darah, bukan juga dari pilihan bebas, tetapi dari pertemuan yang kebetulan dan tidak dapat dielakkan yang dikumpulkan berdasarkan usia dan berbagai kondisi sosial yang hampir sama. Serta sebagai sarana untuk melatih anak dalam kehidupan kolektif (kelompok), kebutuhan untuk terikat kepada kekuatan-kekuatan kolektif.

Dengan diberikannya pendidikan moral bagi anak diharapkan dapat merubah perilaku anak, sehingga jika sudah dewasa lebih bertanggung jawab dan menghargai sesamanya dan mampu menghadapi tantangan jaman yang cepat berubah. Di sinilah pentingnya nilai-nilai moral yang berfungsi sebagai media transformasi manusia Indonesia agar lebih baik, memiliki keunggulan dan kecerdasan di berbagai bidang, baik kecerdasan emosional, kecerdasan sosial, kecerdasan spiritual. Peran orang tua serta guru hanya sebatas memberi hal terbaik sesuai dengan jiwa jaman yang sedang dihadapi saat ini, agar kelak anak, bagaikan anak panah yang lepas dari busurnya, mengatasi permasalahannya sendiri, namun memiliki keunggulan moral yang baik dan luhur. Moral juga menggambarkan kualitas watak sekaligus kepribadian seseorang, karena dengan peningkatan pertimbangan moral 
pada diri anak yang dirancang secara sengaja melalui pendidikan di sekolah ataupun di rumah, dapat membantu pembentukan kepribadian seseorang, karena dengan terbentuknya pertimbangan moralnya, seseorang akan berperilaku sesuai dengan cara berpikir moral yang ada padanya.

\section{SIMPULAN}

Sebagai simpulan, Ada tiga unsur yang ditetapkan oleh Durkheim, yang pertama adalah disiplin, yang kedua adalah keterikatan pada kelompok serta unsur yang ketiga adalah otonomi. Ketiga unsur ini dibutuhkan setiap individu untuk bisa menjadi pribadi yang bermoral. Disiplin moral mengajarkan untuk tidak bertindak sesuai dengan keinginan-keinginan yang hanya bersifat sesaat, yang mengakibatkan tingkah laku yang hanya setaraf dengan kecenderungankecenderungan alamiah belaka. Disiplin pada dirinya sendiri merupakan faktor pendidikan "suigeneris". Manusia menurut Durkheim, pada dasarnya adalah produk masyarakat, dan masyarakat jugalah yang meneruskannya dari satu generasi ke generasi berikutnya, dan secara moral pun semakin lengkap jika merasa dirinya menyatu dengan kelompok yang berbeda-beda di mana ia terlibat: keluarga, perkumpulan, negara dan umat manusia seluruhnya. Kecenderungan kesadaran moral menghubungkan moralitas suatu tindakan dengan otonomi pelakunya adalah suatu kenyataan yang tidak dapat dikesampingkan dan yang harus diperhitungkan.

Konsep pendidikan moral di Indonesia saat ini sudah sangat memprihatinkan. Sistem Pendidikan Nasional di Indonesia sebagaimana tertuang dalam Undang-Undang No.2/89 Sistem Pendidikan Nasional dengan tegas merumuskan tujuannya pada Bab II, Pasal 4 yang berbunyi: Mengembangkan manusia Indonesia seutuhnya. Tujuan tersebut sebenarnya sudah sangat lengkap untuk mendidik anak menjadi pribadi yang utuh dan mandiri dilandasi akhlak dan budi pekerti yang luhur, namun sepertinya sentuhan aspek moral sangatlah kurang.

Tahap anak-anak menurut Durkheim terbagi atas dua tahap, yang pertama hampir seluruhnya berlangsung dalam keluarga, dan 
kedua berlangsung di sekolah dasar. Tahap yang kedua, merupakan tahap kritis dalam pembentukan sikap moral, dan jika tahap kedua ini berlalu, yakni sesudah masa sekolah, belum diletakkan dasar-dasar moralitas, maka dasar-dasar moralitas itu tidak akan pernah tertanam dalam diri anak. Maka di Indonesia sebaiknya menanamkan pendidikan mengenai moral sejak dini terutama di sekolah kepada anak, untuk membantu mempertinggi tingkat pertimbangan, pemikiran, dan penalaran moralnya. Tingkat pemikiran dan pertimbangan moral terbukti secara empiris dapat ditingkatkan melalui pendidikan moral.

Pendidikan bagi Durkheim merupakan sarana sosial untuk tujuan sosial, dan guru merupakan agen masyarakat, mata rantai yang sangat penting, mempunyai tugas untuk menciptakan manusia sesuai dengan citra masyarakat, tetapi pendidikan bukan hanya mengembangkan individu yang sesuai dengan kodratnya atau hanya mewujudkan apa yang belum terlihat dalam pribadi individu, namun pendidikan menciptakan makhluk baru (Elle cree dans l'homme un etre nouveau).

\section{DAFTAR PUSTAKA}

Abdullah T, Leeden der Van, 1986, Durkheim dan Pengantar Sosiologi Moralitas, Yayasan Obor Indonesia, Jakarta.

Asdi, Endang. D, 2003, Manusia Seutuhnya Dalam Moral Pancasila, Pustaka Raja, Yogyakarta.

Barnadib, Imam, 1982, Filsafat Pendidikan, Sistem dan Metode, Andi Offset, Yogyakarta.

Bertens, K, 2007, Etika, Gramedia Pustaka Utama, Jakarta.

Budianto, Dua (ed.), 2007, Etika Terapan, Meneropong Masalah Kehidupan Manusia Dewasa ini, Yayasan Kota Kita, Jakarta.

Djiwandono, Sri E.W, 2006, Psikologi Pendidikan, Grasindo, Jakarta

Durkheim, E, 1973, Moral Education A Study in the Theory and Application of The Sociology of Education, alih bahasa: Everest K Wilson and Herman SchnurerThe Free Press of Glencoe, New York. 1989, Sosiologi dan Filsafat, alih bahasa: Soedjono Dirjosiswa, Erlangga, Jakarta. 
1990, Pendidikan Moral, Suatu Studi Teori dan Aplikasi Sosiologi Pendidikan, alih bahasa: Lukas Ginting, Erlangga, Jakarta.

Go. P.TA, 1982," Pendidikan Moral Umat", Majalah Orientasi.

Hadi, Hardono. P, 1996, Jati Diri Manusia Berdasar Filsafat Organisme A.N Whitehead, Kanisius, Yogyakarta.

Hardiman, Budi, 1987, “Pendidikan Moral Sebagai Pendidikan Keadilan", Majalah Basis.

Harefa, A, 2002, Sekolah Saja Tidak Pernah Cukup, Gramedia Pustaka Utama, Jakarta.

Hazlitt, H, 2003, Dasar-Dasar Moralitas, Pustaka Pelajar Offset, Yogyakarta.

Hericahyono, Cheppy, 1995, Dimensi-dimensi Pendidikan Moral, IKIP Semarang Press, Semarang.

Huijbers, Theo, 1986, Manusia Merenungkan Makna Hidupnya, Kanisius, Yogyakarta.

Isjoni, 2006, Membangun Visi Bersama; Aspek-aspek Penting dalam Reformasi Pendidikan, Yayasan Obor Indonesia, Jakarta.

Jamrah, Suyan,1983, Emile Durkheim Tentang Agama, Skripsi, Fakultas Ushulud-din, Yogyakarta.

Muhni, I, 1994, Moral dan Religi Menurut Emile Durkheim dan Henri Bergson, Kanisius, Yogyakarta.

Sahide, A, 2010, Kebebasan Dan Moralitas, PAS, Yogyakarta.

Saksono, G, Ign, 2008, Pendidikan yang Memerdekakan Siswa, Rumah Belajar Yabinkas, Yogyakarta. 2010, Tantangan Pendidikan Memecahkan Problem Bangsa, Tanggapan Terhadap Pembatalan UU BHP, Forkoma PMKRI, Yogyakarta.

Setiawan, Benni, 2006, Manifesto Pendidikan di Indonesia, Ar-Ruzz, Yogyakarta.

Sjarkawi, 2006, Pembentukan Kepribadian Anak, Peran Moral Intelektual, Emosional, dan Sosial Sebagai Wujud Integritas Membangun Jati Diri, Sinar Grafika Offset, Jakarta.

Soekanto, Soerjono, 1985, Emile Durkheim Aturan-Aturan Metode 
248 Jurnal Filsafat, Vol. 26, No. 2, Agustus 2016

Sosiologis, Rajawali, Jakarta.

Sunarso, dkk, 2006, Pendidikan Kewarganegaraan, UNY Press, Yogyakarta.

Suseno, F, Magnis, 1986, Kuasa dan Moral, Gramedia, Jakarta.

1987, Etika Dasar Masalah-Masalah Pokok Filsafat Moral, Kanisius, Yogyakarta.

Tjahjadi, L, 1991, Ajaran Immanuel Kant Tentang Etika Dan Imperatif Kategoris, Kanisius, Jakarta.

Zuriah, N, 2007, Pendidikan Moral dan Budi Pekerti Dalam Perspektif Perubahan, Bumi Aksara, Jakarta.

Www.edublogs. ;Sylvie, 19 September 2006; Pendidikan Moral Manusia.

Www.multiplysite.com ; christy's Site, Jun 19, '08 7:24 AM ; Pendidikan di Indonesia harus punya nilai pragmatis (John Dewey). 